Krzysztof Langowski

Warszawa

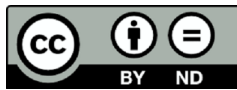

\title{
Początki działalności Instytutu Józefa Piłsudskiego w Nowym Jorku (1943-1956). Część 2 (1951-1956)
}

Zarys treści: Druga część artykułu poświęcona jest ludziom, którzy włożyli ogromny wysiłek w budowę niezależnej placówki naukowej, starali się gromadzić i opracowywać dokumenty historyczne, ale także popularyzować wiedzę dotyczącą Polski i jej historii. Instytut Piłsudskiego finansowo wspierany był przez działaczy polonijnych, składki członkowskie oraz większe wpłaty czynione przez niektórych członków.

Słowa kluczowe: Nowy Jork, Instytut Józefa Piłsudskiego, środowisko niepodległościowe w USA

Key words: New York, Joseph Pilsudski Institute, Independence enviroments in USA

Instytut poniósł w 1951 r. dotkliwe straty wskutek śmierci kolejnych znaczących dla swej działalności postaci. Odeszli: prezes Instytutu Stefan Łodzieski i jego wiceprezes Henryk Floyar-Rajchman. Członek-korespondent Instytutu, ambasador Juliusz Łukasiewicz popełnił zaś samobójstwo w Waszyngtonie. 10 kwietnia 1953 r. zmarł kolejny założyciel Instytutu, jego ówczesny prezes Franciszek Januszewski. To odejście było tym bardziej dotkliwe, gdyż planował on $\mathrm{w}$ tym czasie zakup budynku na terenie Nowego Jorku z przeznaczeniem właśnie na potrzeby Instytutu ${ }^{1}$.

W kolejnych latach rozwijała się współpraca Instytutu z wieloma innymi instytucjami zarówno na terenie Stanów Zjednoczonych, jak i poza ich granicami. Do wymienionych już Fundacji Kościuszkowskiej i Polskiego Instytutu Naukowego w Nowym Jorku, a także Muzeum Polskiego w Chicago dołączyły m.in. Biblioteka Watykańska, British Museum, Yale University, Biblioteka Polska w Paryżu, Polski Uniwersytet na Obczyźnie z siedzibą w Londynie, Alliance College w Cambridge Springs w Pensylwanii, Biblioteka Kongresu w Waszyngtonie, Polski Uniwersytet

\footnotetext{
1 Komunikat IJP, październik 1953 r., s. 2.
} 
w Londynie, University of California w Los Angeles, Journal of Central Europien Affairs-University of Colorado w Boulder (Colorado) ${ }^{2}$.

Interesujące było w tym czasie podejście ludzi kierujących Instytutem do instytucji Free Europe. Sam Wacław Jędrzejewicz stwierdził wówczas, że „jest to typowa obca agentura [...] jest ona wysunięta na pierwszy plan przez Departament Stanu i Bedell-Smitha z Central Intelligence Service. [...] Robią bardzo ciekawy biuletyn prasy krajowej i różne zestawienia, na pewno dobrze robione. Ustaliliśmy tu, że nie przeszkadzamy naszym ludziom tam pracować: [Edward] Kleszczyński, [Kazimierz] Wierzyński, [Jan] Lechoń, [Adam] Koc, gen. Wincenty Kowalski. Póki nie znajdą innej pracy. [...] Robota parszywa, jak widzisz. Trudno jej przeciwdziałać, bo kupują ludzi. Czasem nawet nic za to nie wymagają, jak od Wierzyńskiego lub Lechonia. Wydaje mi się, że jedyną taktyką jest ta, którą się prowadzi: wykazywanie, co to jest naprawdę i co się za tym kryje. Nie bojkotowanie ludzi, którzy tam pracują"3.

W 1956 r. na wniosek Rady Instytutu powołano płka Romana Michałowskiego na delegata w celu nawiązania łączności z amerykańskimi instytucjami i fundacjami naukowo-historycznymi. Utworzono także po raz pierwszy sekcję naukowo-doradczą Instytutu, na czele której stanął prof. Oskar Halecki. W jej szeregach znaleźli się profesorowie, członkowie-korespondenci nowojorskiej placówki: A. Coleman, Marian Kamil Dziewanowski, Ludwik Krzyżanowski, Eugeniusz Kusielewicz, Wacław Lednicki, Zygmunt Nagórski, Bolesław Szczęśniak, Michał Sokolnicki. Podjęto także akcję zachęcania do pisania i gromadzenia relacji historycznych osób, które brały udział w pracach i walkach o niepodległość Polski w „ostatnim 50-leciu". Utworzono także sekcję tzw. młodej generacji wywodzącej się z polonijnej emigracji. Starano się w ten sposób ożywić werbunek nowych członków z podkreśleniem przy tym konieczności pozyskania do współpracy z placówką właśnie pracowników naukowych oraz młodej generacji polonijnej emigracji. Zwiększono częstotliwość prac Rady, co spowodowało, że w 1956 r. odbyło się osiem posiedzeń tegoż gremium. W trakcie zebrania Rady Instytutu zdecydowano wówczas powołać na dyrektora wykonawczego gen. Wincentego Kowalskiego. Zastępcą dyrektora i jednocześnie kierownikiem sekcji studiów i archiwów mianowano płka Adama Koca. W Komunikacie wydanym przez Instytut w lipcu 1956 r. znalazła się notatka zatytułowana „Wielka strata” informująca o nagłej śmierci w dniu 8 VI 1956 r. Jana Lechonia (Leszka Serafimowicza). Autorzy pisali wówczas „Jeden z największych społecznych poetów i pisarzy był również stałym członkiem i współpracownikiem Instytutu od chwili jego powstania. Wkład pracy Jana Lechonia w działalność Instytutu był bardzo duży i wprost nieoceniony. Cześć jego pamięci”4.

2 Protokół z IX Walnego Zgromadzenia z 29 V 1952 r. w Woodrow Wilson Memorial Foundation; Sprawozdanie na X Walne Zgromadzenie Członków Instytutu w dn. 4 VI 1953 r. w sali Woodrow Wilson Foundation.

3 AOG w IJP, NY, Wacława Jędrzejewicza; list Wacława Jędrzejewicza do Tadeusza Schaetzla, Wellesley, 16 XII 1951 r., zesp. 53, t. 2, k. 53.

${ }^{4}$ Sprawozdanie dyrektora Damiana Wandycza na XIII Walne Zgromadzenie Członków Instytutu w dniu 12 V 1956 r., s. 4; Sprawozdanie Instytutu za rok 1956, luty 1957, s. 1, 2; Komunikat Prasowy 
Rada Instytutu rozpoczęła w tym czasie prace nad analizą i przygotowanie niektórych zespołów ze zgromadzonych zbiorów archiwalnych, które miałyby zostać udostępnione zgłaszającym się do Instytutu pracownikom naukowym. Dotyczyło to następujących zbiorów:

a) Powstanie styczniowe 1863 r. Dokumenty gen. Waleriana Płatonowa,

b) Powstania Górnośląskie. Dokumenty te nie były do tego czasu udostępniane historykom,

c) Udział Polaków w I wojnie światowej. Zestaw dokumentacji zebranej i przygotowanej przez gen. Juliana Stachiewicza ${ }^{5}$.

Pokłosiem zmian w Instytucie były także rozważania niektórych członków z nowych władz Instytutu w kwestii dotychczasowego politycznego zaangażowania placówki oraz związane $\mathrm{z}$ nimi decyzje. $Z$ zachowanej korespondencji wyłania się obraz takich przemyśleń, o których poinformowani zostali niektórzy członkowie Instytutu, a w tym m.in. prof. Wacław Lednicki, do którego Adam Koc pisał: „my tutaj byliśmy głęboko zatroskani o los Instytutu, który z wolna zamierał, nie mając jasno wytyczonej linii, według której miał się rozwijać. Dlatego na wiosnę br. postanowiliśmy we trzech (prezes Instytutu p[an] Henryk Korab Janiewicz, gen. Wincenty Kowalski i ja [Adam Koc]) wyprostować niedomówienia i odchylenia od właściwego toru działalności i określenia zadań Instytutu. Dziś Instytut nastawiony jest na drogę ściśle naukowo-historyczną. Nie służy żadnej specjalnej kapliczce politycznej ani zajmuje się gloryfikacją poszczególnych osób. Natomiast podejmuje dalszy ciąg pracy zainicjowanej przez Józefa Piłsudskiego. [...] gloryfikowanie poszczególnych osób - nie jest zadaniem Instytutu”. Podobny w treści list wysłany został także do Bogusława Kunca, w którym A. Koc napisał: „Chcę zwrócić Ci uwagę, że Instytut stoi $\mathrm{z}$ dala od walk wewnętrzno-politycznych polskich [...] Wobec rozbicia się polskiego na obozy (zamkowy i zjednoczeniowy) - wyłączyliśmy Instytut poza obręb tych walk, nie wchodząc w nie, natomiast ściśle trzymając się linii naukowej"'.

\section{Kwestia zorganizowania archiwum i biblioteki Instytutu}

W biuletynie z $1951 \mathrm{r}$. zamieszczono informacje o przekazanych do Instytutu darach i depozytach do archiwum. Zjednoczenie Polskie na terenie strefy amerykańskiej Niemiec dostarczyło do Instytutu akty Zrzeszenia Ośrodków Polskich w Bawarii Północnej, Ośrodków Polskich Wildflaken i Ludwigsberg, wraz z krótką monografią w opracowaniu mgra Jerzego Ptakowskiego. Otto Szymański, który był prezesem Ogniska Zjednoczenia Polskich Uchodźców w Amberg na terenie Niemiec, przesłał

IJP w nowej fazie swojej działalności, s. 1; Komunikat Instytutu J. Piłsudskiego, lipiec 1956, s. 1, 3; AOS w IJP, NY, teczka Jerzego Breynaka, Kontrakt, 15 VIII 1956 roku.

${ }^{5}$ Sprawozdanie prezesa Instytutu na XIV Walne Zgromadzenie Członków Instytutu, 14 III 1957 r., s. 2, 3; Sprawozdanie Instytutu Józefa Piłsudskiego w Ameryce za rok 1956, luty 1957 r., s. 2, 3.

6 AOS w IJP, NY, teczka Wacława Lednickiego, list Adama Koca do Wacława Lednickiego, Nowy Jork, 17 XII 1956 r.; AOS w IJP, NY, teczka Kunca Bogusława, list Adama Koca do Bogusława Kunca, Nowy Jork, 29 IX 1956 r. 
16 paczek zawierających archiwum tejże organizacji. Wacław Studnicki, który przybył do Stanów Zjednoczonych, zdeponował także w archiwum Instytutu archiwum należące do Zjednoczenia Polskiego w Niemczech oraz materiały ukazujące życie i pracę polskich wysiedleńców na tych właśnie terenach. Archiwa te stanowiły uzupełnienie przekazanych już wcześniej materiałów z Niemiec. Do Instytutu wysłano też archiwum Henryka Floyar-Rajchmana. W jego skład wchodziło „wiele tysięcy listów, dokumentów, notatek, opracowań, relacji, książek, prasy i wycinków. Całość tego materiału jest już posortowana i rozklasyfikowana"7.

W 1951 r. dr Anna Mars przekazała do zbiorów Instytutu ocalałe egzemplarze odezw i ulotek wytworzonych w czasie walk o niepodległość w latach 1916-1918. Instytut zwracał się przy okazji z apelem do wszystkich, którzy posiadali wszelkie materiały o wartości historycznej, o deponowanie ich w nowojorskiej placówce, gdzie „zostaną pieczołowicie przechowane dla użytku publicznego. Materiały o charakterze poufnym będą używane zgodnie z wolą i zastrzeżeniami ofiarodawców"8.

Zapoznając się z treścią sprawozdań z działalności Instytutu, znajdujemy dużo informacji o przekazywanych do archiwum placówki archiwaliach gromadzonych przez różne instytucje, redakcje gazet i tygodników oraz osoby prywatne. Jako przykład może posłużyć relacja z 1953 r., w której znajdujemy m.in. dane, iż Komisja Główna Skarbu Narodowego w Londynie przekazała komplet wytworzonych przez siebie materiałów; Zarząd Główny KNAPP w Nowym Jorku kontynuował stałe przekazywanie pism i broszur; Liga Niepodległości Polski zarówno działająca w Anglii, jak i we Francji podarowała komplety pism; redakcja czasopisma „Polak w Kaliforni” działająca w San Francisco oddała komplet pism i broszury; J. Biłasiewicz z Chicago przekazał 350 wycinków prasowych; Koło Żołnierzy AK w Nowym Jorku dostarczyło komplet wytworzonych pism; Damian Wandycz podarował własne zbiory archiwalne, w tym m.in. broszury i korespondencję; Biblioteka Polska w Paryżu przekazała 9 broszur, 18 pism i pamiętniki, Zbigniew Spotowski z Nowego Jorku przesłał 30 broszur, 650 pism polskich, 14 pamiętników i 4 albumy; Klaudiusz Hrabyk z Nowego Jorku przekazał 48 broszur, 515 polskich pism, 8 pamiętników, 400 wycinków prasowych, dr Wacław Gawroński z Toledo w Ohio oddał szereg kompletów czasopisma „Polityka Narodów”, materiały dotyczące stosunku Polonii amerykańskiej do J. Piłsudskiego, komplet wycinków z prasy polskiej w Ameryce po zgonie Marszałka, album karykatur Marszałka wykonanych przez Zdzisława Czermańskiego. Były ambasador RP w Bukareszcie Leon Orłowski przekazał do biblioteki Instytutu wiele cennych książek i broszur9.

W 1954 r. Instytut zakupił tzw. Archiwum Waleriana Płatonowa. Zbiór ten przetrwał kilkadziesiąt lat nierozpoznany i właściwie w zapomnieniu w Paryżu we francuskiej części rodziny żony Waleriana Płatonowa. Po zidentyfikowaniu jego war-

7 Biuletyn Instytutu Józefa Piłsudskiego nr 1, wrzesień 1951, s. 2.

8 Biuletyn Instytutu Józefa Piłsudskiego nr 2, marzec 1952, s. 2.

9 Sprawozdanie przygotowane na XI Walne Zgromadzenie Członów Instytutu; Komunikat Instytutu Józefa Piłsudskiego, październik 1953 r., s. 2. 
tości, został on przeznaczony na sprzedaż i przesłany do Stanów Zjednoczonych. Archiwum to składało się z rękopisów, aktów, druków, korespondencji z okresu 1861-1863, które stanowi część spuścizny po byłym ministrze cara, jednocześnie będącym sekretarzem stanu dla spraw Królestwa Polskiego. W skład archiwum weszły 43 teczki obejmujące łącznie ponad 1300 kart, które z małymi wyjątkami dotyczyły jedynie spraw polskich. Wśród nich znajdują się m.in. obszerny memoriał autorstwa Siergieja Szypowa (w rękopisie) przesłany cesarzowi Aleksandrowi II, a dotyczący całokształtu polityki rosyjskiej w stosunku do Polski; protokoły z posiedzeń Izby Rolniczej w Warszawie i organizacji kupiectwa w Warszawie. Przede wszystkim są tam materiały dotyczące powstania styczniowego: rozkazy powstańcze, instrukcje dowódców, prasa powstańcza („Strażnica”, „Ruch”, „Wiadomości z placu boju”), a ze strony rosyjskiej: odezwy, zarządzenia władz itd. Wśród kilkuset listów pisanych po francusku, polsku i rosyjsku znajdują się listy autorstwa margrabiego Aleksandra Wielopolskigo, hrabiego Fiodora Berga, księcia Michała Gorczakowa i wielu innych ${ }^{10}$. W tymże samym roku do Instytutu trafiły także zbiory przekazane przez Stefanię Bardziłowską z Bostonu, które dotyczyły opieki społecznej nad członkami Polskich Sił Zbrojnych w czasie wojny. Wiesław Frontczak z Detroit przekazał zbiór prasy polskiej, którą gromadził. J. Szlichciński przesłał zbiór druków i czasopism z okresu działalności KON. Kłopoty finansowe Instytutu komplikowały możliwości związane z gromadzeniem i opracowywaniem zbiorów. Jak zaznaczono w wydanym Komunikacie: „Dotychczas, zbiory archiwalne [...] są magazynowane bardzo ciasno: w trzech odległych miejscach: płatne - biuro Instytutu i przechowalnia towarowa, oraz bezpłatna - komórka piwniczna domu czynszowego p[ana] W. Malewicza w New Yorku". Wydatki związane z przechowywaniem w tym czasie własności Instytutu w różnych miejscach były znaczne, lecz nader rzadko wykazywane w sprawozdaniach finansowych (choć np. w Sprawozdaniu za 1953 r. widnieje suma: 421,30 dolarów) ${ }^{11}$. Dzięki bezpośredniej pracy sekretarza Instytutu Jana Kowalskiego zbiory te zostały wówczas w swej najbardziej wartościowej części scalone i ciasno ulokowane w trzech pokojach wynajmowanych przez Instytut. Realizacja tego zamysłu stała się także możliwa po części dlatego, że Jerzy Braynack ofiarował Instytutowi komplet nowych półek wykonanych z metalu, które właśnie umożliwiły rozmieszczenie zarówno zbiorów archiwalnych, jak i bibliotecznych. Dzięki temu można było przystąpić także do należytego zabezpieczenia i jednocześnie sprawniejszego udostępnienia do badań zgromadzonych do tego czasu materiałów. Przede wszystkim przystąpiono do uporządkowania i fachowego zewidencjonowania posiadanych oraz wciąż napływających do placówki zbiorów. Zaznaczano jednak, że niezbędna w tym celu miała być pomoc polskiej społeczności przebywającej na emigracji. Oprócz wsparcia finansowego, które umożliwiłoby wynajęcie odpowied-

${ }^{10}$ Protokół z XII Walnego Zgromadzenia Członków Instytutu z dn. 12 IV 1955 r. w Woodrow Wilson Foundation w Nowym Jorku; Komunikat Instytutu, grudzień 1955, s. 1, 2; Sprawozdanie sekretarza Instytutu Jana Kowalskiego z posiedzenia Rady Instytutu w dniu 4 VI 1954 roku.

${ }^{11}$ Sprawozdanie z działalności Instytutu za rok 1953 (sprawozdanie finansowe), s. 1. 
nich pomieszczeń m.in. właśnie na archiwum, potrzebna była pomoc ochotników do prowadzenia prac porządkujących $\mathrm{w}$ archiwaliach. Pozytywnym przykładem takiego właśnie zaangażowania jest sekretarz tej placówki, Jan Kowalski, który uporządkował i zinwentaryzował polską prasę pochodzącą z 41 krajów. Realizacja bibliografii historyczno-politycznej Polski, która była opracowywana w latach 40 . i na początku 50., ,została przerwana i zaniechana od czterech lat $\mathrm{z}$ powodu braku środków. Bibliografia ta niezbędna jest w Instytucie dla studiów najnowszej historii polskiej. Wznowienie tej niezbędnej dziedziny pracy oraz odrobienie zaległości jest pilną koniecznością". Powoływano się przy tym na wydany duży tom podobnej bibliografii wszystkich krajów świata, ale tylko w latach 1942-1952, który został opracowany i opublikowany rok wcześniej przez Council of Foreign Affairs w Nowym Jorku: „nie wyczerpuje żaden wyżej wymienionej bibliografii polskiej”"12. Podjęto także szeroką akcję gromadzenia i opracowywania relacji osób uczestniczących w walce i pracach o niepodległość Polski przed, w czasie, a także po zakończeniu II wojny światowej.

\section{Kwestie wydawnicze Instytutu}

W 1953 r. wydano broszurę O zapomnianym liście Piłsudskiego do Masaryka autorstwa Damiana Wandycza. Była to odpowiedź na wydaną wówczas książkę Winstona Churchilla ${ }^{13}$.

W 1954 r. Instytut opublikował broszurę Polish Americans and Curzon Line, której udokumentowaną treścią starano się odpowiedzieć na oświadczenie wydane przez prezydenta Franka Delno Roosevelta w 1944 r. w Jałcie, stwierdzające, że Polonia Amerykańska popierała tzw. „Linię Curzona” jako granicę polsko-sowiecką. Jak pisał Damian Wandycz, „Wiemy, że przeciwnie, Polonia czyniła wszystko, aby nie dopuścić do oderwania od Polski ziem wschodnich i wobec tego nie może pozostawać pod krzywdzącym zarzutem, że się do tego przyczyniła"14.

Rok później w 1955 r. Rada Instytutu zdecydowała o przystąpieniu do wydania 2 i 3 tomu Poland in the British Parliament. Jak zaznaczono w sprawozdaniu dyrektora Instytutu, „Anonimowy ofiarodawca zgłosił gotowość udzielenia Instytutowi na ten cel pożyczki w wysokości 2/3-ich kosztów druku, płatnej z wpływów ze sprzedaży książki. Instytut ze swej strony musi zaangażować się tylko w 1/3-ej. Drugi tom został już przez p[ana] W. Jędrzejewicza przygotowany do druku. Przygotowanie trzeciego tomu jest na ukończeniu"15.

Niewątpliwą zasługą Instytutu było wsparcie, jakiego udzielono Władysławowi Pobóg-Malinowskiemu w wydaniu jego pracy „Najnowsza historia polityczna

12 Komunikat Instytutu Józefa Piłsudskiego, lipiec 1956 r., s. 2; Sprawozdanie Instytutu Józefa Piłsudskiego, luty 1957 r., s. 1.

13 Sprawozdanie dyrektora Damiana S. Wandycza za rok 1953.

14 AOS w IJP, NY, teczka Marii Kosko, list Damiana Wandycza do Marii Kosko, Nowy Jork 5 XI 1954 roku.

15 Sprawozdanie dyrektora Damiana Wandycza na Walne Zgromadzenie Członków Instytutu w dniu 12 V 1956 r., s. 2. 
Polski", którą realizowano pomiędzy latami 1952-1960. Świadczy o tym niewątpliwie korespondencja prowadzona z poszczególnymi dyrektorami Instytutu oraz z W. Jędrzejewiczem. Instytut poza dostarczaniem informacji niezbędnych do historycznego opracowania, gromadził także przedpłaty od chętnych na planowane wydanie tej pozycji, które miały spłacić druk i wysyłkę kolejnych tomów. Wydłużający się termin opublikowania kolejnych zeszytów, które na dodatek autor znacznie rozbudowywał, opóźniał samo ich dotarcie do czytelników, a jednocześnie powodował ich pretensje adresowane bezpośrednio do samego Instytutu. Starając się uspokoić podenerwowanych subskrybentów, którzy wpłacili już zaliczkę, w oficjalnym komunikacie pisano, iż „Z wiadomości otrzymanych od autora, druk książki miał być ukończony we wrześniu, a książka rozesłana w październiku. Trudności towarzyszące wydanie II-go tomu spowodowały dalsze opóźnienia”. Spodziewano się jednakże, że w ciągu najbliższych kilku tygodni Instytut otrzyma egzemplarze dla subskrybentów w Ameryce. Podkreślano przy tym, że objętość tomu 2 „będzie znacznie większa, niż to było preliminowane. Zamiast projektowanych 350 stron, tom liczyć będzie blisko 700”. Na temat swej sytuacji i powiększania się objętości pracy pisał także Władysław Pobóg-Malinowski, stwierdzając, że jest „zmęczony, wyczerpany niesamowicie. [...] Poza tym żyję w nerwowym napięciu. Wiem, że rozgrzesza mnie i usprawiedliwia zwłokę - obok nienormalnych warunków emigracyjnych - powiększenie i całości Historii (prawie trzykrotnie), i drugiego zwłaszcza tomu - ponad dwukrotnie". Dodatkowo Władysław Pobóg-Malinowski uzyskał ze strony Instytutu stypendium na ostateczne dokończenie całości, a placówka wystąpiła w roli gwaranta dla kanadyjskiego dystrybutora, którym była księgarnia „Mosaic Publishers Co."16.

Ważnym elementem działalności wydawniczej środowiska niepodległościowego skupionego w Instytucie było podjęcie się odtworzenia redagowania „Niepodległości”. Pomysł wznowienia wydawania tego przedwojennego biuletynu, ukazującego się w okresie międzywojennym w Instytucie Józefa Piłsudskiego w Warszawie, wyprzedził nawet powstanie Instytutu w Londynie, który podjął się jego kontynuacji. Wiązał się on $\mathrm{z}$ krótkim pobytem gen. Władysława Bortnowskiego w Kanadzie i Stanach Zjednoczonych w 1946 r. i prowadzonymi wówczas rozmowami z Ignacym Matuszewskim, Henrykiem Floyar-Rajchmanem, Wacławem Jędrzejewiczem i Franciszkiem Januszewskim na temat ponownego wydawania pisma. Ślady tych

${ }^{16}$ AOG w IJP, NY, Władysława Pobóg-Malinowskiego, list Wacława Jędrzejewicza do Władysława Pobóg-Malinowskiego, Wellesley, 21 V 1951 r., zesp. 85, k. 454; ibidem, list Władysława Pobóg-Malinowskiego do Wacława Jędrzejewicza, Paryż, 25 IV 1952 r., k. 480; ibidem, list Władysława Pobóg-Malinowskiego do Wacława Jędrzejewicza, Paryż, 12 VIII 1952 r., k. 270; Komunikat Instytutu Józefa Piłsudskiego, grudzień 1955 r., s. 3. Ibidem, list Władysława Pobóg-Malinowskiego do Wacława Jędrzejewicza, Paryż, 22 XI 1953 r., k. 511; ibidem, list Władysława Pobóg-Malinowskiego do Wacława Jędrzejewicza, Paryż, 3 I 1955 r., k. 524; ibidem, list Władysława Pobóg-Malinowskiego do W. Jędrzejewicza, Paryż, 10 IV 1956 r., k. 527; ibidem, list Władysława Pobóg-Malinowskiego do Wacława Gawrońskiego, sygn. XLII/A; ibidem, list Władysława Pobóg-Malinowskiego do gen. Wincentego Kowalskiego, t. Va/2Arch IJP, NY, protokół z posiedzenia Rady Instytutu J. Piłsudskiego w Ameryce 22 XI 1952 roku. 
rozmów znajdujemy w jednym z listów, w którym gen. Bortnowski stwierdzał: „uchwaliliśmy wspólnie ze śp. Franciszkiem Januszewskim, że będziemy wydawać miesięcznik pt. 'Niepodległość. Miało to być pismo przeznaczone dla wszystkich kontynentów, miało ono dotrzeć wszędzie tam, gdzie są Polacy i miało mieć charakter polityczny i historyczny. Wydawcą miał być prezes Franciszek Januszewski, redaktorem Ignacy Matuszewski. Nie było jeszcze wtedy mowy o tworzeniu Instytutu na terenie Londynu. Ostatnią rozmowę z Ignacym Matuszewskim w tej sprawie miałem 3 czerwca $1946 \mathrm{r}^{\prime \prime}{ }^{17}$. W trakcie przygotowań do drugiego posiedzenia Rady Instytutu J. Piłsudskiego w Londynie w kwietniu 1947 r. nadeszło pismo od Wacława Jędrzejewicza z Nowego Jorku, w którym zamieszczony był projekt przygotowywanego statutu dla powstającej placówki. Znalazła się tam także uwaga, że: „Instytut w Nowym Jorku ma zamiar kontynuować dzieło Walerego Sławka, Prystora i Leona Wasilewskiego przez wydawanie właśnie pod tym samym tytułem, zbiorowym wysiłkiem pisma historycznego, analogicznego do wydawanego przed wojną w Warszawie - 'Niepodległość”'18. Wypowiedź Wacława Jędrzejewicza była pokłosiem listu autorstwa Władysława Bortnowskiego, w którym zaznaczał, że „Piłsudczycy [chodziło o środowisko związane z Bronisławem Hełczyńskim i Michałem Grażyńskim, przeciwko któremu zdecydowanie występowali piłsudczycy, jak wcześniej Ignacy Matuszewki, Wacław Jędrzejewicz, Henryk Floyar-Rajchman, Mikołaj Dolanowski, i inni - K.L.] chcą tu wydawać pismo. Chwała Bogu, że nareszcie coś ich do tego pchnęło. Mniejsza z tym ale: Pismo ma nosić nazwę 'Niepodległość. Ta nazwa ma swoją tradycję jako wydawnictwo Instytutu. W razie gdybyśmy chcieli ją wznowić choćby na początek w postaci rocznika, wydawanego wspólnymi siłami NY+my-ew[entualnie] jeszcze jako filia-będziemy 'bez tytułu”. Gen. Władysław Bortnowski starał się w ten sposób zabezpieczyć na przyszłość możliwość dostępu londyńskiej filii Instytutu do kart periodyku. Dlatego też zwracając się do Wacława Jędrzejewicza, pisał m.in. „W każdym razie chociaż nowojorski [Instytut] musi się w tej materii wypowiedzieć. Julek [Łukasiewicz] mi mówil, że ty o tych zamiarach jesteś poinformowany. Proszę zajmij stanowisko [...] Streszczam się: 1. Proszę o zajęcie stanowiska w sprawie odstąpienia tytułu pisma 'Niepodległość. 2. Proszę w razie pozytywnego rozstrzygnięcia, o zostawienie dla Instytutu właściwego miejsca w postaci rubryk lub dodatków"19.

W rezultacie prowadzonej korespondencji, już podczas posiedzenia Rady 22 kwietnia 1947 r., w paragrafie 4. określającym główne zadania Instytutu (pkt 2, podpunkt d Statutu) znalazł się zapis: wydawanie czasopisma „Niepodległość”. Bezpośrednią przyczyną, która jednak wpłynęła na przyspieszone wznowienie edycji „Niepodległości”, było ukazanie się pierwszego numeru „Dziejów Najnowszych”,

17 AOS w IJP, NY, teczka Konrada Libickiego, list gen. Władysława Bortnowskiego do Damiana Wandycza, Londyn, 12 XII 1953 roku.

18 J. Zuziak, Instytut Józefa Piłsudskiego w Londynie, Londyn 2002, s. 22, 23; AOS w IJP, NY, teczka Tadeusza Schaetzela, list Wacława Jędrzejewicza do Tadeusza Schaetzela, Nowy Jork, kwiecień 1947 roku.

19 AOG w IJP, NY, list gen. Władysława Bortnowskiego do Wacława Jędrzejewicza, Londyn, zesp. 37, 5 IV 1947 roku. 
wydawanych przez utworzony w Warszawie Instytut Pamięci Narodowej. Pismo to miało swym zakresem treściowym obejmować okres, którym zajmowała się redakcja przedwojennej „Niepodległości”. Tadeusz Munich pisał wówczas: „Instytut i ‘Dzieje Najn[owsze]' to twory administracji warszawskiej, które miało zastąpić Instytut J. P. i 'Niepodległość'. Niepokojono się także, iż współpracę z nowym pismem podjęły dwie znane postacie z przedwojennego Instytutu J. Piłsudskiego - Henryk Wereszycki i Wanda Kiedrzyńska ${ }^{20}$.

Zgodnie z założeniami zarządu londyńskiego Instytutu postanowiono wydać pierwszy numer rocznika (po wznowieniu) z datą 19 marca 1948 r., czyli w pierwszą rocznicę działalności Instytutu. Prace redakcyjne zlecono Janowi Starzewskiemu i Konradowi Libickiemu. Wówczas także utworzono listę stałych współpracowników spoza Wielkiej Brytanii. Zdecydowano jednakże, że w wydawaniu pisma opierać się będą przede wszystkim na członkach Instytutu. Nad całością programu czuwał gen. Władysław Bortnowski. 6 sierpnia 1947 r. zarząd Instytutu wraz z redakcją „Niepodległości” wystosował pismo do potencjalnych współpracowników, przedstawiając im zarówno linię, jak i główne założenia projektowanego pisma. Stwierdzono w nim, że „Instytut Józefa Piłsudskiego dla Badania Najnowszej Historii Polski Oddział w Londynie przystępuje do wydania pierwszego Rocznika, poświęconego najnowszej historii Polski, ze specjalnym uwzględnieniem ideologii i działalności kierunków niepodległościowych". Redakcja planowała zamieszczać przede wszystkim prace omawiające następujące okresy:

1. Zagadnienia polskie w latach 1794-1914.

2. Działalność Marszałka Piłsudskiego w czasie walki podziemnej i legionowej oraz okres dwudziestolecia niepodległości państwowej.

3. Okres II wojny światowej aż do dzisiaj z punktu widzenia polskiego wkładu dziejowego zarówno w kraju, jak i za granicą.

Prace przeznaczone do umieszczenia w roczniku mogły dotyczyć polskich wysiłków wojennych, dyplomatycznych i organizacyjnych, jawnych i konspiracyjnych, rozwoju ideologii politycznej, zagadnień narodowościowych, jak i procesów społecznych oraz gospodarczych. Starano się otrzymywać teksty poświęcone charakterystyce i działalności wybitnych przedstawicieli życia narodowego. Szczególnie zwracano uwagę na dokładne opracowania akcji, co do których bezpośredni uczestnicy mogli podać mało znane przyczynki i wyjaśnienia. Osobny rozdział pisma według założeń redakcji - miały stanowić osobiste wspomnienia kontaktów z marszałkiem Józefem Piłsudskim i najbliższymi jego współpracownikami. Starano się także zachować wysoki poziom naukowy, przede wszystkim przez oparcie jego treści na źródłach pochodzących z pierwszej ręki oraz przez obiektywizm i pogłębione opracowanie. Zarząd Instytutu i redaktorzy pisma wyrażali przekonanie, że wielu

${ }^{20}$ AOG w IJP, NY, list Tadeusza Schaetzla do Wacława Jędrzejewicza, zesp. 53, Kair, 2 VIII 1947 r., k. 117-126; ibidem, Kair, 8 VIII 1947, k. 130-131; AOG w IJP, NY, zesp. 91, t. 45 f, list Tadeusza Schaetzla do Michała Sokolnickiego, Kair, 9 VIII 1947 r., k. 155; Od redakcji, „Dzieje Najnowsze”, t. 1, styczeń-marzec 1947 roku. 
autorów w tym czasie posiadało rękopisy, które byłyby warte opublikowania, oraz nadające się do zamieszczenia wspomnienia w zakresie ich zainteresowań. Pod koniec 1947 r. pierwszy numer „Niepodległości” pod względem prac redakcyjnych był nieomal na ukończeniu.

W pracach ściśle redakcyjnych współpracowano z Instytutem w Nowym Jorku. Świadczą o tym słowa Wacława Jędrzejewicza skierowane do Michała Sokolnickiego, w których stwierdził, że w Nowym Jorku nie ma możliwości wydania właśnie rękopisu autorstwa Michała Sokolnickiego, ale postanowił przesłać ten fragment „pamiętnika o ruchu strzeleckim do Londynu, by go tam wydrukowano. Jestem teraz w korespondencji z Libickim w tej sprawie"21. Pierwszy tom rocznika oddano do druku w Niemczech, do Londynu dotarł dopiero na przełomie 1948/1949 r. i został natychmiast bezpłatnie rozesłany do wszystkich członków Instytutu. Do Instytutu w Nowym Jorku wysłano 110 egzemplarzy, które także w dużej mierze przekazano członkom Instytutu. W zamieszczonej na s. 7 nocie od redakcji czytamy: „Wydawnictwo 'Niepodległość' wznowione zostaje w Londynie, jako organ Instytutu Józefa Piłsudskiego poświęconego badaniu najnowszej historii polskiej, w ścisłym porozumieniu z głównym jego ośrodkiem w New Yorku. Zmienione warunki życia polskiego wpłynęły na treść wydawnictwa. Składają się na nią samodzielne opracowania, dotyczące walk i wysiłków polskich od chwili rozbiorów po dzień dzisiejszy. W Polsce niepodległej główny dział wydawnictwa stanowiły dokumenty i wspomnienia. Redakcja dążyć będzie w przyszłości do powiększenia liczby wspomnień i do uwzględnienia również materiałów źródłowych". Przygotowaniem pierwszego i drugiego tomu zajął się Konrad Libicki. W marcu 1951 r. ukazał się tom trzeci, jego opracowaniem zajmował się już Komitet Organizacyjny, w którego skład wchodzili wówczas: Stanisław Biegański, Konrad Libicki, Józef Moszczeński i Tadeusz Schaetzel. Komitet w tym samym składzie przygotował także tom czwarty periodyku. W 1955 r. ukazał się kolejny, piąty numer „Niepodległości”. W składzie Komitetu Redakcyjnego nastąpiły zmiany. Znaleźli się w nim wówczas: Stanisław Biegański, Józef Moszczeński, Kazimierz Okulicz, Józef Poniatowski, Tadeusz Schaetzel (przewodniczący Komitetu i jego redaktor) oraz Jan Starzewski.

\section{Kwestia zakupu domu dla Instytutu}

Kolejne kroki prowadzące do zakupu domu podjął następny prezes Instytutu Franciszek Januszewski, który 20 grudnia 1951 r. oświadczył, że „osobiście zakupi dla placówki dom w Nowym Jorku". Informował przy tym, że z powodu swego wyjazdu na dłuższy czas ,udziela pełnomocnictwa dla zakupienia odpowiedniego obiektu p[anu] Stefanowi Roppowi, przy czym proponuję wybór Komisji, która by wraz z p [anem] [Stefanem] Roppem mogła dokonać najbardziej celowego wyboru, p[anów] W[acława] Jędrzejewicza, I[gnącego] Nurkiewicza. Prezes Januszewski

${ }^{21}$ J. Zuziak, op. cit., s. 25, 27; AOG w IJP, NY, list Zarządu IJPL i redakcji „Niepodległości” do przyszłych współpracowników z 6 VIII 1947 r., zesp. 37; AOG w IJP, NY, list Wacława Jędrzejewicza do Michała Sokolnickiego, Nowy Jork, 24 I 1948 r., zesp. 91, t. 45g. 
zaprasza do Komisji D[amiana] S. Wandycza i K[azimierza] Wierzyńskiego". Wówczas także na wniosek Kazimierza Wierzyńskiego Rada przyjęła jednogłośną uchwałę, w której dziękowała za decyzję prezesa, a także podkreślała, że: „Prezes Januszewski nawiązuje do wielkich wzorów szczodrości na cele patriotyczne i najlepszych dbałości o kulturę narodową ${ }^{22}$. Na temat Instytutu i planów związanych z zakupem budynku Józef Lipski rozmawiał z działaczami polonijnymi (w tym ze Stanisławem Gieratem i Edwardem Kleszczyńskim) podczas jednej ze swoich wizyt w Nowym Jorku. W swej relacji pisanej do nieznanej osoby stwierdził, że: „Z wiadomości polonijnych istnieje zamiar ufundowania przez [Franciszka] Januszewskiego gmachu w Nowym Jorku dla Instytutu J. Piłsudskiego"23.

Na temat planów prezesa pisał także Wacław Jędrzejewicz: „Jak wiesz, pracowałem ostatnio w grudniu z [Franciszkiem] Janusz[ewskim] nad sprawą przyszłości Instytutu. Rezultat: nie zdołaliśmy namówić [Walentego] Porańskiego i innych polskich milionerów na większe pieniądze dla Instytutu, [Franciszek] Januszewski postanowił uruchomić sumę 40-50.000 dol[arów] sam i kupić dom dla Instytutu w New Yorku[...] Jesteśmy teraz wszyscy zajęci realizacją tego planu. Ja raczej sztabowo, ze względu na odległość Bostonu od New Yorku (pracuję 10 mil od Bostonu), ale inni na miejscu. Chodzi o wyszukanie odpowiedniego obiektu do zakupienia na wiosnę" ${ }^{24}$. Zgodnie z podjętą decyzją przedstawiciele Instytutu kontynuowali korespondencję ze Stefanem Roppem, który na stałe był w tym czasie zatrudniony w redakcji „Dziennika Polskiego” (American Publishing Corporation) w Detroit. Świadczy o tym list autorstwa Stefana Roppa do dyrektora Instytutu Damiana Wandycza, w którym zwracał się z pytaniem: „Podobno ma Pan na widoku jakiś obiekt, któryby odpowiadał naszym warunkom zarówno pod względem rentowności jak i rozkładu pomieszczeń wewnątrz". Prosił także o szybkie przesłanie podstawowych danych dotyczących owego budynku, czyli jego położenia, wysokości płaconych przez dotychczasowych lokatorów czynszów za poszczególne mieszkania, stanu hipoteki i zestawu planowanych wydatków. Jak twierdził, „materiał ten da mi możność porównania $\mathrm{z}$ innymi obiektami, jakie mi już zakomunikowano dotychczas" 25 . W miarę możliwości w realizację zakupu budynku angażował się sam Wacław Jędrzejewicz, który przyjeżdżał w tym celu $\mathrm{z}$ Bostonu. W jednym $\mathrm{z}$ listów do Damiana Wandycza pisał, że właśnie zgodnie z wcześniejszymi ustaleniami wybierał się w piątek wieczorem pociągiem tuż po zakończeniu popołudniowych wykładów ze studentami „i zaraz po przyjeździe zadzwonię do Pana by umówić się

${ }^{22}$ Biuletyn Instytutu, Relacja z posiedzenia Rady Instytutu, Nr 2, marzec 1952, s. 1, 2; Komunikat Prasowy wydany po Walnym Zgromadzeniu Instytutu w dn. 29 V 1952 r. w sali Woodrow Wilson Foundation, s. 1; AOS w IJP, NY, teczka Franciszka Januszewskiego, list Damiana Wandycza do Franciszka Januszewskiego z 16 I 1952 roku.

${ }^{23}$ AOG w IJP, NY, List Józefa Lipskiego do nieznanej osoby, 16 I 1952 r., s. 1, zesp. 67, t. 39.

24 AOG w IJP, NY, list Wacława Jędrzejewicza do Władysława Bortnowskiego, 21 I 1952 r., zesp. $37, \mathrm{~V} / \mathrm{t} 3 / \mathrm{D}$.

${ }^{25}$ AOS w IJP, NY, teczka Franciszka Januszewskiego, list Stefana Roppa do Damiana Wandycza, Detroit, 7 II 1952 r. 
na sobotę rano. Proponuję jeśli to Panu dogadza, spotkanie np. w Instytucie w sobotę o 10.30 lub 11.00. Moglibyśmy pogadać i obejrzeć dom. [...] Wczoraj widziałem się z Kazimierzem Wierzyńskim, który tu jest w Bostonie na parę dni. Mówił mi on o swoich wrażeniach odnośnie domu przy $37-$-ej ulicy" ${ }^{26}$. W rezultacie wynajęto agentkę panią De Porceri, pośredniczącą w wyszukiwaniu odpowiednich ofert, czyli odpowiadających warunkami budynkom Instytutu. Oceniono m.in. budynek przy 108 East 37 ulicy, który miał kosztować 130 tysięcy dolarów, w tym 38 tysięcy miano natychmiast przy zakupie płacić gotówką, a 92 tysiące miano pożyczyć na ten cel $\mathrm{z}$ banku pod zastaw hipoteczny. Kolejny budynek mieścił się przy 18 East 80 ulicy. Ten miał kosztować 115 tysięcy. Stefan Ropp podkreślał jednak, że jego zdaniem budynki na nowojorskim Manhattanie zmieniają swoich właścicieli zazwyczaj po „wyższych cenach jak nasze oferty". Ponadto sugerował, iż zbliżały się gwałtowne spadki cen na rynku nieruchomości, które były spowodowane ciągłym ruchem w budownictwie, a co za tym idzie „dojdzie do poważnego obniżenia czynszów i wszystkie kalkulacje oparte na obecne kontrakty czynszowe będą zupełnie nierealne za 2 lata. Sugerował także ciągły odpływ mieszkańców na peryferia Nowego Jorku, co także dodatkowo miało przynieść obniżkę wartości nieruchomości. Dlatego biorąc pod uwagę zakup obiektu dla instytucji, mamy na uwadze czynniki zabezpieczające kapitał i dochód. [...] Oglądałem sam cztery inne obiekty, które jednakże zupełnie się nie nadawały, aczkolwiek ceny były niskie". Sam jednakże zdawał sobie sprawę, iż oferty finansowe, które złożył dotychczasowym właścicielom budynków, „przyjęte nie będą. Jednakże może kontroferty będą bliższe temu, co możemy dać. Zobaczymy, jaka będzie reakcja" ${ }^{27}$. Kilka dni później Wacław Jędrzejewicz pisał, że właśnie powrócił do Wellesley z Nowego Jorku, gdzie obejrzał dwa domy, które zostały zakwalifikowane do zakupienia przez Stefana Roppa i Franciszka Januszewskiego. Wacław Jędrzejewicz następnie stwierdził, „gdzie długo rozmawiałem z właścicielem, oraz ogólnie oglądałem dom na 80 ulicy. Wydaje mi się, że z nich ten pierwszy nadaje się lepiej dla potrzeb Instytutu i jest więcej pewny pod względem dochodowości”. Jednakże na podstawie rozmowy z właścicielem budynku przy 37 ulicy, Wacław Jędrzejewicz zorientował się, że nie przystanie on na ofertę Instytutu w proponowanej sumie 130 tysięcy dolarów, która „mogłaby spotkać się w krakowskim targu z ceną p[ana] Gulaka [właściciela budynku]. Najwyżej można spodziewać się, że właściciel opuści około 5000 dol[arów], tj. że cena sprzedażna wyniesie 160.000”. Wacław Jędrzejewicz optował zdecydowanie za zakupieniem owego budynku, gdyż uważał, że pomimo tak wysokiej ceny, dawał on w planach na przyszłość podstawy pozytywnej egzystencji Instytutu. W dalszej części listu Wacław Jędrzejewicz zaznaczył, że przeciwny zakupowi tegoż budynku był z kolei Kazimierz Wierzyński, któremu nie podobało się jego położenie w niebezpiecznej dzielnicy. Wacław Jędrzejewicz

${ }^{26}$ AOS w IJP, NY, teczka Kazimierza Wierzyńskiego, list Wacława Jędrzejewicza do Damiana Wandycza, Wellesley, 2 III 1952 roku.

27 AOS w IJP, NY, teczka Franciszka Januszewskiego, list Stefana Roppa do Damiana Wandycza, Detroit, 5 III 1952 roku. 
nie podzielał tego zdania, chwaląc tę właśnie lokalizację ze względu na bliskość po sąsiedzku z biblioteką Morgana i nowojorską Biblioteką Publiczną mieszczącą się przy 5 Alei, róg 42 ulicy. Wacław Jędrzejewicz pisał dalej, że: „Ulica jest ruchliwa, to prawda, ale wszystkie te ulice są takie. W następnym bloku na rogu Lexington Ave i 37-ej ulicy jest bardzo dobry Shelburn Hotel, naprzeciwko naszego obiektu jest American Society of University Woman, bardzo szacowna instytucja. Tak, że nie uważam, iż położenie tego domu miało go dyskredytować dla naszych potrzeb”28. Zarówno prezes Franciszek Januszewski, jak i Stefan Ropp wyrażali w korespondencji wymienianej z Wacławem Jędrzejewiczem oraz Damianem Wandyczem, że wkrótce nastąpi obniżenie cen nieruchomości. Stefan Ropp stanowczo stwierdził, że „gdyby zniżka ceny nie wyniosła poważniejszej sumy, nie mógłbym doradzić p[anu] [Franciszkowi] Januszewskiemu zakupu domu”. Poza tym podkreślał z przekonaniem, że z pewnością „Jesteśmy w okresie, w którym należy spodziewać się znacznej zniżki wartości domów. Załamanie koniunkturalne i poważna depresja przyjdą prawdopodobnie w początku 1953 roku. Do tego czasu, propaganda wyborcza i okres gwiazdkowy nie dopuszcza do poważniejszego załamania”. Całość sugestii proponowanej przez Stefana Roppa zawarta w obszernej korespondencji ukazywała raczej niechęć do zrealizowania przyrzeczenia złożonego przez Stefana Januszewskiego co do zakupu odpowiedniego pomieszczenia dla Instytutu. Dało się to też zauważyć w słowach Damiana Wandycza, który przypomniał potrzebę współpracy przy próbach czynionych wokół planowanego zakupu w ciągu minionego czasu, które aż do końca 1952 r. nie przyniosły pozytywnych rezultatów, gdyż „czekaliśmy na spadek cen, lub okazyjne kupno. Oferta, którą panu ostatnio przyniosłem była o $25 \%$ tańsza, niż w roku ubiegłym. Zdaniem Pana jest to jednak cena wygórowana. O ile dobrze zrozumiałem, zaleca Pan zaczekać z kupnem na spodziewany kryzys, który umożliwi kupno domu za bezcen. Obawiam się jednak, że to oddalałoby całą rzecz na czas zupełnie nieokreślony. Kryzys na odcinku realnościowym może nadejść, ale może $\mathrm{z}$ równym powodzeniem i nie nadejść. Wiemy jak przewidywania $\mathrm{w}$ tej mierze, zwłaszcza w czasie są zawodne"29.

Podczas Walnego Zgromadzenia Członków Instytutu, które odbyło się 5 czerwca 1953 r., prezes Franciszek Januszewski przepraszał, że jeszcze nie miał możliwości zrealizowania zakupu domu dla Instytutu, ale jak stwierdził - „podjął niezłomne postanowienie" w celu realizacji swej obietnicy. Wszelkie jednak poważne plany związane z rychłym zakupem budynku legły w gruzach wraz z nagłą śmiercią prezesa Franciszka Januszewskiego (10 czerwca 1953 r. w Detroit). Członkowie Instytutu zostali powiadomieni o zaistniałej sytuacji za pomocą specjalnego komunikatu. $\mathrm{Na}$ pogrzebie Instytut reprezentowany był przez wiceprezesa Edwarda Kleszczyńskiego i dyrektora Damiana Wandycza, który osobiście nad grobem żegnał także prezesa w imieniu nowojorskiej placówki. Prezes jednakże pamiętał o Instytucie, czyniąc

${ }^{28}$ Ibidem, list Wacława Jędrzejewicza do Stefana Roppa, Wellesley, 11 III 1952 roku.

${ }^{29}$ Ibidem, list Stefana Roppa do Damiana Wandycza, Detroit 18 III 1952 r.; ibidem, list Damiana Wandycza do Stefana Roppa, Nowy Jork, 7 II 1953 roku. 
z niego jednego ze swoich spadkobierców. Według krążących wówczas - i prawdę powiedziawszy nieoficjalnych - pogłosek, testament przewidywał, że $1 / 3$ jego majątku, która została przeznaczona żonie, miała się stać w przyszłości własnością Instytutu. Pragnąc ratować sytuację i podtrzymać przy życiu plany zakupu budynku, działacze Instytutu zdecydowali w dniu 26 czerwca 1953 r. w trakcie posiedzenia Rady, że w jej szeregi zostanie wprowadzona wdowa po prezesie, pani Stefania Januszewska ${ }^{30}$. Jednakże nadal nie wiedziano właściwie nic o zakresie donacji, jaką w rzeczywistości prezes Franciszek Januszewski przeznaczył Instytutowi. Jak twierdził wówczas Wacław Jędrzejewicz: „Prywatnie nam mówiono, że suma 40.000 dol[arów] jest na to przewidziana, ale jak zaznaczyłem, nie mamy tego czarno na białym ani też warunków, jeśli w ogóle są, co do użycia tej sumy. Liczymy jednak z Damianem Wandyczem, z którym długo to omawiałem, że jednak suma ta wpłynie w tym roku. Wówczas-tylko nie wiemy kiedy - przystąpimy do kupna domu, co zajmie sporo czasu. Suma powyższa zmaleje do jaki[ch]ś 33.000 na dom, bo trzeba zachować parę tysięcy na remont i wprowadzenie się, wraz z instalacją sprzętów do pracy"31.

Wysokość sumy spadkowej przypadającej w stosunku 1/3 majątku mającej przypaść Instytutowi po śmierci pani Stefanii Januszewskiej potwierdzał także Stefan Ropp. Nie był jednak w stanie wówczas stwierdzić, czy powyższy zapis pokrywał sumę ofiarowaną na zakup budynku, gdyż nie było to jeszcze w tym czasie wyjaśnione od strony prawnej. Podkreślał przy tym, że „ofiara na dom był prywatna, natomiast osobistym majątkiem zmarłego była część akcji American Publishing. Wszystkie inne składniki należały do wdowy. Sprawy te będą wyjaśnione przez adwokatów w najbliższym czasie" ${ }^{\prime 2}$.

Wkrótce też rozwiały się wszelkie nadzieje na uzyskanie niezbędnej sumy ze spadku po Franciszku Januszewskim. Urealniła to treść relacji Klaudiusza Hrabyka, który przeprowadził rozmowę z gen. Kazimierzem Sosnkowskim w domu Alfreda Jurzykowskiego w Bronxwille w stanie Nowy Jork. Otóż gen. Sosnkowski był właśnie po spotkaniu ze Stefanem Roppem, który potwierdził całkowity upadek planów związanych z otrzymaniem przez Instytut jakichkolwiek sum ze spadku po Franciszku Januszewskim. Stefan Ropp stanowczo wówczas stwierdził, że „na ten cel z majątku [Franciszka] Januszewskiego nie pozostały żadne pieniądze i nie należy mieć żadnych nadziei, aby można było coś na dom Instytutu uzyskać o ile p[ani][Stefania] Januszewska, wdowa, nie zapisze w przyszłości ze swojego majątku na ten cel. Gen. [Kazimierz] Sosnkowski był tą wiadomością głęboko przejęty"33.

Już w trakcie posiedzenia Rady Instytutu w dniu 19 kwietnia 1955 r. do kwestii posiadania własnego domu przez Instytut powrócił gen. Władysław Bortnowski. Podkreślił on wówczas konieczność jego zakupu, gdyż „nie ma widoków na to,

${ }^{30}$ Komunikat IJP w Nowym Jorku, październik 1953 roku.

31 AOG w IJP, NY, list Wacława Jędrzejewicza do Władysława Pobóg-Malinowskiego, Wellesley 20 VII 1953 r., zesp. 85, t. XLII/A/2.

32 AOS w IJP, NY, teczka Stefana Roppa, list Stefana Roppa do Damiana Wandycza, Detroit 24 VII 1953 roku.

33 AOG w IJP, NY, zapiski z rozmowy z gen. Kazimierzem Sosnkowskim, zesp. 48, t. III/A. 
aby można w bliskiej przyszłości liczyć na zrealizowanie spadku po św. pamięci [Franciszku] Januszewskim, należy przystąpić do zakupu domu w drodze specjalnej zbiórki na ten cel". Generał proponował połączenie tej akcji z uczczeniem Marszałka J. Piłsudskiego w dwudziestolecie jego śmierci i zaproponował jednocześnie utworzenie komitetu ds. budowy domu. W dyskusji, która się wówczas wywiązała, brali udział wszyscy obecni na tym spotkaniu: prezes Henryk Korab-Janiewicz, gen. Władysław Bortnowski, Damian Wandycz, Jan Kowalski, Stefan Lenartowicz, Ignacy Nurkiewicz, Juliusz Kanarek. Ignacy Nurkiewicz uważał, że istniały małe szanse na zgromadzenie niezbędnych funduszy na zbudowanie własnego budynku Instytutu. O wiele realniejsze jego zdaniem wydawało się stworzenie wspólnego domu, który pomieściłby wiele polskich organizacji, o czym - jak podkreślał - mówiło się od dawna, a w którym znalazłoby się miejsce także i dla samego Instytutu. Panowie Henryk Korab-Janiewicz, Wiesław Domaniewski i Stefan Lenartowicz nie widzieli możliwości zgromadzenia odpowiedniej sumy na budowę własnego domu za pomocą planowanej zbiórki. Gen. Władysław Bortnowski podkreślał ze swej strony, że sprawa nie jest zbyt łatwa, ale zaznaczał jednak, że „nie ma na myśli dużego domu w śródmieściu, ale uważa, że jest realne zakup małego domku choćby na peryferiach miasta i proponuje utworzenie Komitetu w tym celu. Zgłasza wniosek, aby tym zajął się dyrektor Instytutu". W odpowiedzi Damian Wandycz stwierdził, że powołanie takiego właśnie komitetu i jego akcja nie mieściły się w bieżących sprawach realizowanych przez biuro Instytutu. Uważał przy tym, że należało w takim razie powołać w tej kwestii komisję specjalną złożoną z członków Rady. Zaproponował także, aby jej powołaniem zajął się właśnie gen. Władysław Bortnowski. Propozycja ta $w$ takiej właśnie formie została wówczas przyjęta ${ }^{34}$.

Rok później w 1956 r. Rada Instytutu podjęła decyzję o zainicjowaniu akcji mającej na celu gromadzenie odpowiednich funduszy, które miały być właśnie przeznaczone na zakup własnej siedziby dla placówki. Postanowienie to motywowano przede wszystkim planami dalszego gromadzenia zbiorów, realizacji studiów nad nimi, wykładami dla publiczności oraz kwestiami administracyjnymi. Całość działalności placówki wymagała więc stanowczo „wielokrotnie zwiększonego pomieszczenia”. Jak wówczas w trakcie dyskusji podkreślano, powinien to być „mały dom w środku New Yorku i tak pomyślany, aby dolna część mogła być odnajęta na sklepy czy instytucje handlowe, z czego dochód opłacałby lokal Instytutu i administracje domu oraz ratę ewentualnego długu hipotecznego". Podkreślano jednakże konieczność posiadania na wstępie odpowiedniego kapitału finansowego. Dlatego też podnoszono potrzebę wspólnej zbiórki pieniędzy na 1957 roku. Po dłuższej dyskusji zdecydowano wówczas przyjąć następującą uchwałę: 1 . Zaplanować i uruchomić „drive” [zbiórkę - K.L.] celem zebrania funduszy na kupno domu Instytutu; 2. Stworzyć „zaczyn” tego funduszu jeszcze przed rozpoczęciem „drive'u” przez zadeklarowanie przez ofiarnych członków Instytutu pierwszych wpłat; 3. Prosić Prezesa Instytutu, aby stanął na czele „drive’u”. W rezultacie wówczas obecni zgłosili następujące deklaracje na plano-

${ }^{34}$ Protokół z posiedzenia Rady Instytutu z dnia 19 IV 1955 r., autorstwa sekretarza Jana Kowalskiego. 
wany Fundusz Domu Instytutu: gen. Władysław Bortnowski - 100 \$, gen. Wincenty Kowalski - 100 \$, Jan Kowalski - 100 \$, mecenas Juliusz Kanarek - 200 \$, Edward Kleszczyński - 100 \$, płk Adam Koc - 100 \$. Stefania Januszewska ze swej strony oświadczyła, że „rozważy jeszcze swoje możliwości i zadeklaruje konkretną sumę w najbliższej przyszłości" ${ }^{35}$. Jak się więc okazało, wszelkie plany związane z zapewnieniem bezpiecznego lokum dla Instytutu nie zostały zrealizowane pomyślnie.

Podsumowując, muszę stwierdzić, że pomimo piętrzących się trudności w początkowym okresie działalności Instytutu, udało się utrzymać go nie tylko „przy życiu”, ale także z powodzeniem rozwijać działalność zarówno archiwalną, jak i wydawniczą. Wysiłki podejmowane wówczas procentowały przez kolejne dziesięciolecia działalności tej nowojorskiej placówki, doprowadzając do jej pomyślnego rozkwitu.

The beginnings of the Józef Piłsudski Institute in New York (1943-1956). Part II (1950-1956).

The second part of this text about Piłsudski Institute in New York is dedicated to people who make efforts to build this independent scientific research institution. They tried not only to collect and organize historical documents, but also to popularize unadulterated knowledge about Poland and its recent history. Piłsudski Institute was based on financial support granted by Polish activists and membership fees as well as larger donations from some members.

Thanks to energetic work of people connected with the institution both archival and library collections grew rapidly. Simultaneously, the Institute published significant sources of recent history of Poland. Documents such as Poland in the British Parliament (Volume 2,3) by Wactaw Jędrzejewicz and two brochures: A forgotten letter of Pitsudski to Masaryk in 1953 and Polish Americans and the Curzon Line published in 1954 prepared by Damian S. Wandycz were published in English.

Начало деятельности Института Юзефа Пилсудского в Нью-Йорке (1943-1956) Часть 2. (1951-1956)

Вторая часть текста, касающегося Института Юзефа Пилсудского в Нью-Йорке посвящена людям построившим это независимое научное учреждение. Они пытались собирать и обрабатывать исторические документы, а также распространять знания о Польше и ее истории. Институт Пилсудского базировал на финансовой поддержке деятелей польской диаспоры, членских взносах и более больших взносах отдельных членов.

Благодаря энергетичной работе людей, связанных с учреждением, собрание быстро увеличивалось (так архивное, как и библиотечное). Параллельно, Институт опубликовал важные источники, касающиеся новейшей истории Польши. На английском были изданы документы, обработанные Вацлавом Енджеевичем Poland in the British Parliament, а также две брошюры авторства Дамиана С. Вандыча Забытое письмо Пилсудского Масарыку и Польские американцы и линия Керзона.

35 Sprawozdanie Instytutu Józefa Piłsudskiego w Ameryce za rok 1956, luty 1957, s. 3; Protokół z posiedzenia Rady Instytutu w dniu 3 XII 1956 r., s. 3. 